\title{
Raman and infrared spectroscopic study of turquoise minerals
}

Jiří Čejka ${ }^{\mathrm{a}, \mathrm{b}}$, Jiří Sejkora ${ }^{\mathrm{a}}$, Ivo Macek ${ }^{\mathrm{a}}$, Radana Malíková ${ }^{\mathrm{a}}$, Lina Wang ${ }^{\mathrm{b}}$, Ricardo Scholz ${ }^{\mathrm{c}}$, Yunfei Xi ${ }^{\mathrm{b}}$, Ray L. Frost ${ }^{\mathrm{b}, *}$

${ }^{a}$ Department of Mineralogy and Petrology, National Museum, Cirkusová 1740, CZ-193 00 Praha 9, Czech Republic

${ }^{\mathrm{b}}$ School of Chemistry, Physics and Mechanical Engineering, Science and Engineering Faculty, Queensland University of Technology, GPO Box 2434, Brisbane, Queensland 4001, Australia

${ }^{\mathrm{c}}$ Geology Department, School of Mines, Federal University of Ouro Preto, Campus Morro do Cruzeiro, Ouro Preto, MG 35,400-00, Brazil

\section{H I G H L I G H T S}

- We have studied the Raman and infrared spectra of turquoise $\mathrm{CuAl}_{6}\left(\mathrm{PO}_{4}\right)_{4}(\mathrm{OH})_{8} \cdot 4 \mathrm{H}_{2} \mathrm{O}$.

- Observed Raman and infrared bands were assigned.

- Approximate $\mathrm{O}-\mathrm{H} \cdots \mathrm{O}$ hydrogen bond lengths were calculated from the Raman and infrared spectra.

- No Raman and infrared bands attributable to $\left(\mathrm{PO}_{3} \mathrm{OH}\right)^{2-}$ units were observed.

\section{A R T I C L E I N F O}

Article history:

Received 14 September 2014

Received in revised form 8 April 2015

Accepted 16 April 2015

Available online 21 April 2015

Keywords:

Turquoise

Phosphate

Hydroxyl ions

Raman spectroscopy

Infrared spectroscopy

\section{G R A P H I C A L A B S T R A C T}

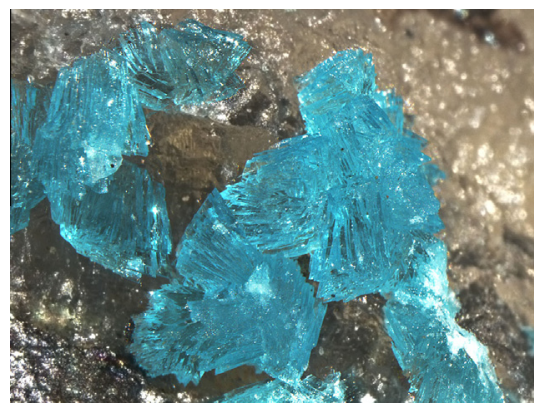

\section{A B S T R A C T}

Raman and infrared spectra of three well-defined turquoise samples, $\mathrm{CuAl}_{6}\left(\mathrm{PO}_{4}\right)_{4}(\mathrm{OH})_{8} \cdot 4 \mathrm{H}_{2} \mathrm{O}$, from Lavender Pit, Bisbee, Cochise county, Arizona; Kouroudaiko mine, Faleme river, Senegal and Lynch Station, Virginia were studied, interpreted and compared. Observed Raman and infrared bands were assigned to the stretching and bending vibrations of phosphate tetrahedra, water molecules and hydroxyl ions. Approximate $\mathrm{O}-\mathrm{H} \cdots \mathrm{O}$ hydrogen bond lengths were inferred from the Raman and infrared spectra. No Raman and infrared bands attributable to the stretching and bending vibrations of $\left(\mathrm{PO}_{3} \mathrm{OH}\right)^{2-}$ units were observed.

(c) 2015 Elsevier B.V. All rights reserved.

\section{Introduction}

The mineral turquoise is one of the oldest gem materials known. Its use in jewellery and for personal decoration can be traced back 70 centuries, to ancient Egypt [1,2]. Today, turquoise is popular in fine jewellery as well as in various cultures, most notably among Native Americans in the south-western United States [1,2]. The first orientation of turquoise studies allows archaeologists to investigate pre-Colombian turquoise trade structures in North America and

\footnotetext{
* Corresponding author.

E-mail address: r.frost@qut.edu.au (R.L. Frost).
}

identify or authenticate the natural sources of turquoise worldwide [3-7]. Various physico-chemical characteristics of turquoise were studied together with questions of turquoise provenance especially with regard to its wealth of colors (blue, green in various shades) and further properties important for its use in jewellery [8-15]. The sources of high-quality gem turquoise are limited and because this material (due to porosity characteristic for massive aggregates) easily accepts many treatments, the majority of gem turquoise are adulterated $[2,16,17]$. Detection of the extent and character of these treatments, inclusive impregnation with polymers, is a very important job especially for use of non-destructive methods [18-21]. 
Turquoise was one of the first gem materials to be simulated by synthetics like glass, plastic, pressed turquoise powder bonded by resin, colored gelmagnesite or howlite [22]. At the present time, synthetic turquoise is produced by the method of Gilson [23]. A set of analytical methods, such as PXRD and EDS analysis or ATRIR, UV-VIS-NIR and Raman spectra are used for distinguishing these artificial replacements from natural turquoise [24]. Last, but not least, turquoise affected by extended exposure to sunlight and water weathered to chalky white minerals; this alteration processes are as yet, poorly understood [3-4].

Most of as yet published papers on turquoise (as mentioned above) are, however, usually, based only on one or several research methods; especially in the case of papers focused to infrared or Raman spectroscopy the data on chemical composition or values of unit-cell parameters of studied mineral phases are mostly missing. The main aim of this paper is to report the Raman and infrared spectra of three well-defined natural untreated turquoise samples from three different occurrences, and to relate the spectra to its molecular and crystal structure. Further aim of the paper is also to certify the possibility to use Raman data for the provenance of turquoise samples; this is the reason why three samples from various localities differing in morphology, color and details in chemical composition were studied. The paper follows the systematic research of the large group of oxyanions containing minerals [25-29], and especially their molecular structure using IR and Raman spectroscopy [30-35].

\section{Background information}

Triclinic mineral turquoise belongs to a turquoise group; general formula for minerals of this group may be written as $\mathrm{A}_{0-1} \mathrm{~B}_{6}\left(\mathrm{PO}_{4}\right)_{4}(\mathrm{OH})_{8} \cdot 4 \mathrm{H}_{2} \mathrm{O}$. Most common substituents at the $A$ position are $\mathrm{Cu}^{2+}, \mathrm{Fe}^{2+} \mathrm{Zn}^{2+}$ or vacancy; at the $B$ position then $\mathrm{Al}^{3+}$ or $\mathrm{Fe}^{3+}[4,36-38]$.

Turquoise usually occurs as apple-green, bluish green, sky-blue or greenish gray fine granular, dense massive to cryptocrystalline aggregates, nodules, crusts or veinlets; small short columnar crystals are rare [1,39]. It has dozens of occurrences but only few produce commercial gem material or contain well-formed crystals $[1,39]$. Turquoise is uncommon supergene mineral formed in the oxidized zone (mainly in arid climates) of phosphorus-rich aluminous rocks (volcanic, phosphate-rich sediments, hydrothermal porphyry deposits, etc.) in the presence of $\mathrm{Cu}$ minerals $[1,39]$.

The unit-cell parameters of turquoise were determined by Graham [40], the first solution of its crystal structure was published by Cid-Dresdner [41]. Recently, the crystal structure of turquoise refined by Kolitsch and Giester [42]. Turquoise contains in its crystal structure $\mathrm{Cu}_{6}$ octahedra, with $\Phi=2 \mathrm{H}_{2} \mathrm{O}$ and $4 \mathrm{OH}^{-}$, two $\mathrm{Al \Phi}_{6}$ octahedra with $3 \mathrm{OH}^{-}, 1 \mathrm{H}_{2} \mathrm{O}$ and $2 \mathrm{O}^{2-}$ and one $\mathrm{Al}_{6}$ octahedron with $4 \mathrm{O}^{2-}$ and $2 \mathrm{OH}^{-}$, and two symmetrically distinct $\left(\mathrm{PO}_{4}\right)^{3-}$ tetrahedra $[41,42]$. No $\left(\mathrm{PO}_{3} \mathrm{OH}\right)^{2-}$ units were observed in its crystal structure $[4,41,42]$. Only in the case of planerite, $\mathrm{Al}_{6}\left(\mathrm{PO}_{4}\right)_{2}\left(\mathrm{PO}_{3} \mathrm{OH}\right)_{2} \cdot 4 \mathrm{H}_{2} \mathrm{O}$, the charge balance should be maintained by the protonation, connected with $\mathrm{Cu}$-site occupancy decrease [36]. However, according to Kolitsch and Giester [42], the charge balance might be also achieved by introducing additional $\mathrm{Cu}^{2+}$ or other cations in the partially occupied site at $(1 / 2,0,1 / 2)$.

\section{Experimental}

\section{Minerals}

The studied samples of the mineral turquoise originated from three different occurrences: Lavender Pit, Bisbee, Cochise county, Arizona (labeled as A) - little greenish cryptocrystalline aggregates

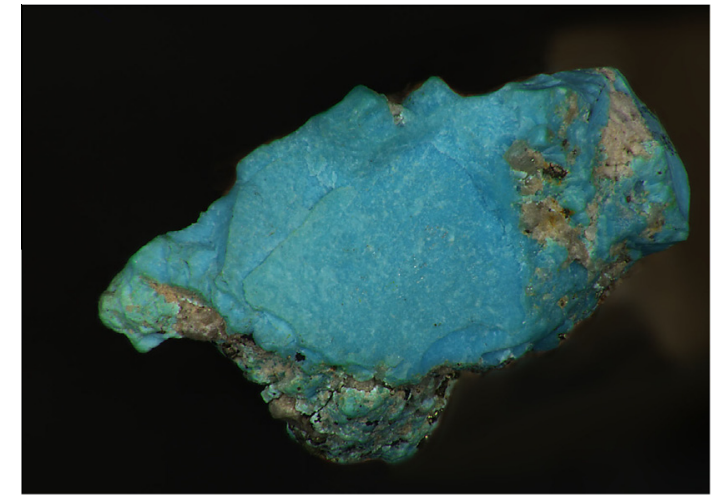

Fig. 1. Cryptocrystalline aggregates of turquoise, Lavender Pit, Bisbee, Cochise county, Arizona. Photo J. Sejkora, FOV $2 \mathrm{~cm}$.

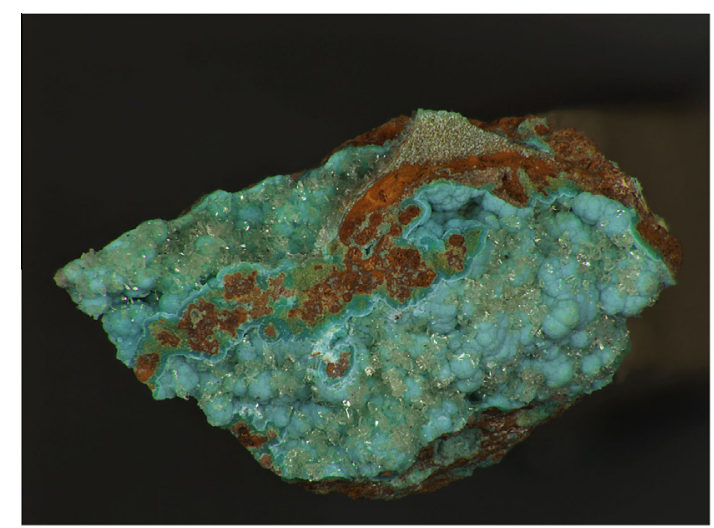

Fig. 2. Light greenish blue globular aggregates of turquoise in association with tiny transparent senegalite crystals, Kouroudaiko mine, Faleme river, Senegal. Photo J. Sejkora, FOV $3 \mathrm{~cm}$. (For interpretation of the references to color in this figure legend, the reader is referred to the web version of this article.)

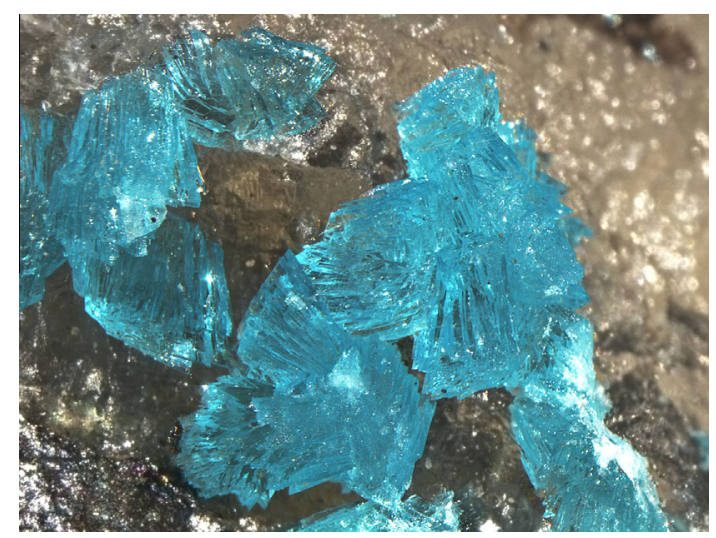

Fig. 3. Groups of transparent dark sky-blue well-formed turquoise crystals up to $2 \mathrm{~mm}$ in size on quartz gangue, Lynch Station, Virginia. Photo J. Sejkora, FOV $1 \mathrm{~cm}$. (For interpretation of the references to color in this figure legend, the reader is referred to the web version of this article.)

up to some $\mathrm{cm}$ in size (Fig. 1); Kouroudaiko mine, Faleme river, Senegal (labeled as S) - light greenish blue globular aggregates up to $3 \mathrm{~mm}$ in size in association with tiny transparent senegalite crystals (Fig. 2); Lynch Station, Virginia (labeled as V) - rich groups of transparent dark sky-blue well-formed crystals up to $2 \mathrm{~mm}$ in size on quartz gangue (Fig. 3). 
Table 1

Unit-cell parameters of turquoise samples (for triclinic space group $P-1$ ).

\begin{tabular}{llllll}
\hline & Virginia & Senegal & Arizona & {$[42]$} & {$[38]$} \\
\hline$a[\AA]$ & $7.411(3)$ & $7.411(5)$ & $7.410(5)$ & $7.410(1)$ & $7.426(8)$ \\
$b[\AA]$ & $7.632(3)$ & $7.635(6)$ & $7.635(6)$ & $7.633(1)$ & $7.634(8)$ \\
$c[\AA]$ & $9.905(4)$ & $9.904(7)$ & $9.901(7)$ & $9.904(1)$ & $9.91(1)$ \\
$\alpha\left[^{\circ}\right]$ & $68.43(3)$ & $68.46(5)$ & $68.43(5)$ & $68.42(1)$ & $68.67(8)$ \\
$\beta\left[^{\circ}\right]$ & $69.65(2)$ & $69.64(5)$ & $69.63(5)$ & $69.65(1)$ & $69.70(8)$ \\
$\gamma\left[^{\circ}\right]$ & $65.05(3)$ & $65.03(5)$ & $65.05(5)$ & $65.01(1)$ & $65.01(8)$ \\
$V\left[\AA^{3}\right]$ & $459.9(3)$ & $460.0(7)$ & $459.7(6)$ & $460.3(1)$ & $461.5(9)$ \\
\hline
\end{tabular}

Table 2

Chemical composition of studied turquoise samples (wt.\%).

\begin{tabular}{|c|c|c|c|c|}
\hline & Virginia & Senegal & Arizona & Ideal \\
\hline $\mathrm{CaO}$ & 0.04 & 0.00 & 0.00 & \\
\hline $\mathrm{FeO}^{*}$ & 0.92 & 0.42 & 0.83 & \\
\hline $\mathrm{BaO}$ & 0.37 & 0.21 & 0.00 & \\
\hline $\mathrm{CuO}$ & 9.76 & 6.17 & 8.61 & 9.78 \\
\hline $\mathrm{ZnO}$ & 0.12 & 0.24 & 0.13 & \\
\hline $\mathrm{Al}_{2} \mathrm{O}_{3}$ & 35.37 & 37.92 & 37.33 & 37.60 \\
\hline $\mathrm{Fe}_{2} \mathrm{O}_{3}^{*}$ & 1.56 & 0.12 & 0.00 & \\
\hline $\mathrm{SiO}_{2}$ & 0.00 & 0.00 & 0.09 & \\
\hline $\mathrm{P}_{2} \mathrm{O}_{5}$ & 33.75 & 35.27 & 34.09 & 34.90 \\
\hline $\mathrm{H}_{2} \mathrm{O}^{* *}$ & 17.52 & 17.90 & 17.62 & 17.72 \\
\hline Total & 99.41 & 98.25 & 98.69 & 100.00 \\
\hline $\mathrm{Ca}^{2+}$ & 0.006 & 0.000 & 0.000 & \\
\hline $\mathrm{Fe}^{2+}$ & 0.108 & 0.047 & 0.095 & \\
\hline $\mathrm{Ba}^{2+}$ & 0.020 & 0.011 & 0.000 & \\
\hline $\mathrm{Cu}^{2+}$ & 1.032 & 0.625 & 0.898 & \\
\hline $\mathrm{Zn}^{2+}$ & 0.013 & 0.023 & 0.013 & \\
\hline$\Sigma \mathrm{Me}^{2+}$ & 1.178 & 0.706 & 1.006 & \\
\hline$\square$ & 0.000 & 0.294 & 0.000 & \\
\hline $\mathrm{Al}^{3+}$ & 5.835 & 5.987 & 6.078 & \\
\hline $\mathrm{Fe}^{3+}$ & 0.165 & 0.013 & 0.000 & \\
\hline$\Sigma \mathrm{Me}^{3+}$ & 6.000 & 6.000 & 6.078 & \\
\hline$\left(\mathrm{SiO}_{4}\right)$ & 0.000 & 0.000 & 0.012 & \\
\hline$\left(\mathrm{PO}_{4}\right)$ & 4.000 & 3.706 & 3.988 & \\
\hline$\left(\mathrm{PO}_{3} \mathrm{OH}\right)$ & 0.000 & 0.294 & 0.000 & \\
\hline$\Sigma \mathrm{T}$ & 4.000 & 4.000 & 4.000 & \\
\hline $\mathrm{OH}$ & 8.356 & 7.706 & 8.236 & \\
\hline $\mathrm{H}_{2} \mathrm{O}$ & 4.00 & 4.00 & 4.00 & \\
\hline
\end{tabular}

$\mathrm{FeO}^{*}$ and $\mathrm{Fe}_{2} \mathrm{O}_{3}^{*}$ contents were calculated on the basis of $\mathrm{Me}^{2+} / \mathrm{Me}^{3+}$ cations; $\mathrm{H}_{2} \mathrm{O}^{* *}$ content was calculated on the basis of charge balance and ideal content of $4 \mathrm{H}_{2} \mathrm{O}$ molecules.

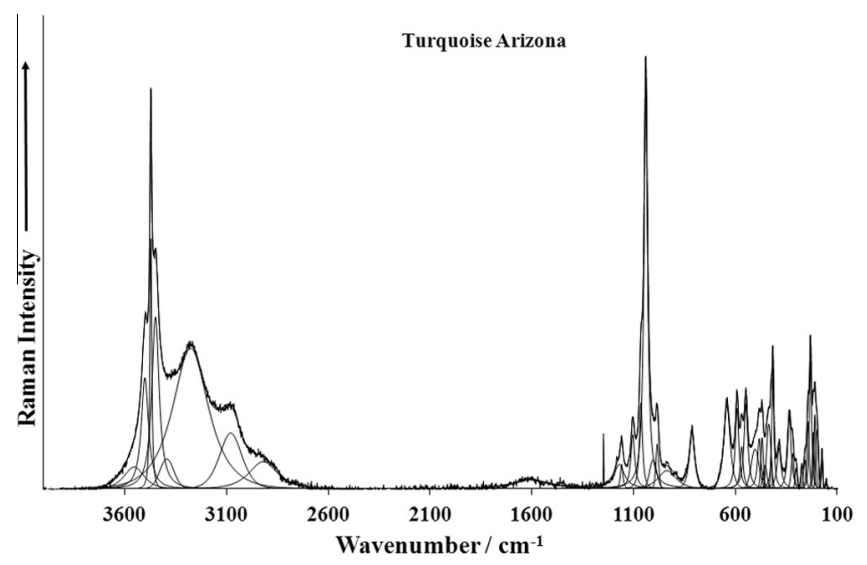

Fig. 4a. Raman spectrum of turquoise sample from Arizona over the 100 $4000 \mathrm{~cm}^{-1}$ spectral range.

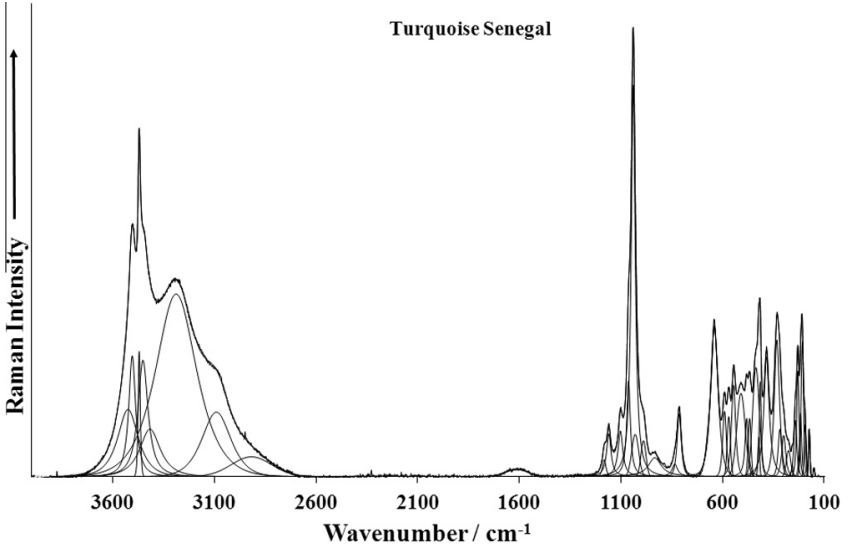

Fig. 4b. Raman spectrum of turquoise sample from Senegal over the 100$4000 \mathrm{~cm}^{-1}$ spectral range.

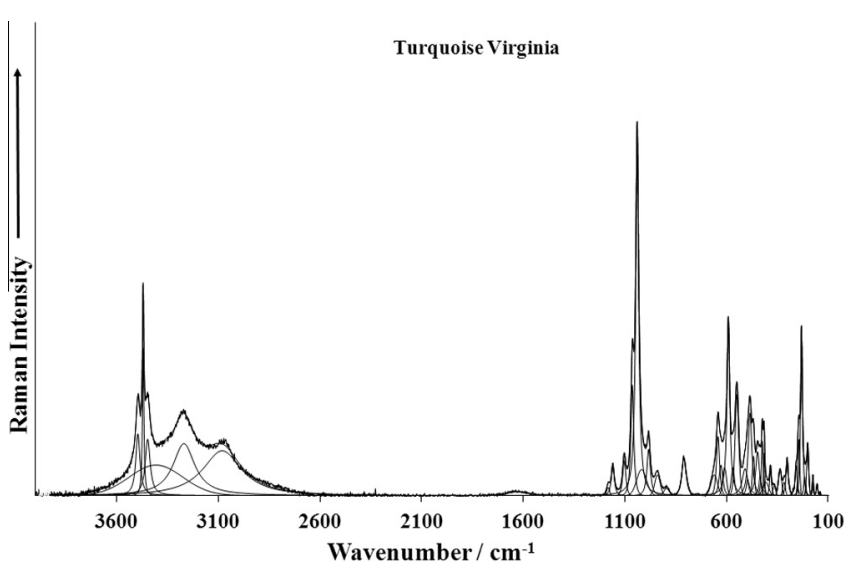

Fig. 4c. Raman spectra of turquoise from Virginia over the $100-4000 \mathrm{~cm}^{-1}$ spectral range.

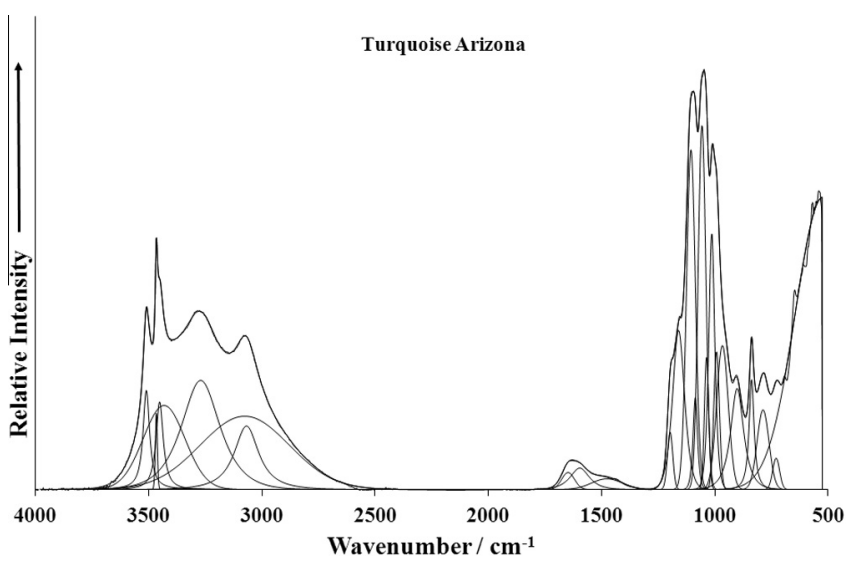

Fig. 4d. Infrared spectra of turquoise from Arizona over the $500-4000 \mathrm{~cm}^{-1}$ spectral range.

Carefully hand-picked samples were used for X-ray powder diffraction experiments. To minimize the complicated shape of background, the samples studied were placed on a flat low-background silicon wafer. Powder XRD measurements were carried out with $\mathrm{CuK} \alpha$ radiation at a Bruker D8 Advance diffractometer $(40 \mathrm{kV}, 40 \mathrm{~mA})$ in the range $4-70^{\circ} 2 \theta$ in the step-scan mode $0.01^{\circ} / 8 \mathrm{~s}$. The position and intensities of reflections were 


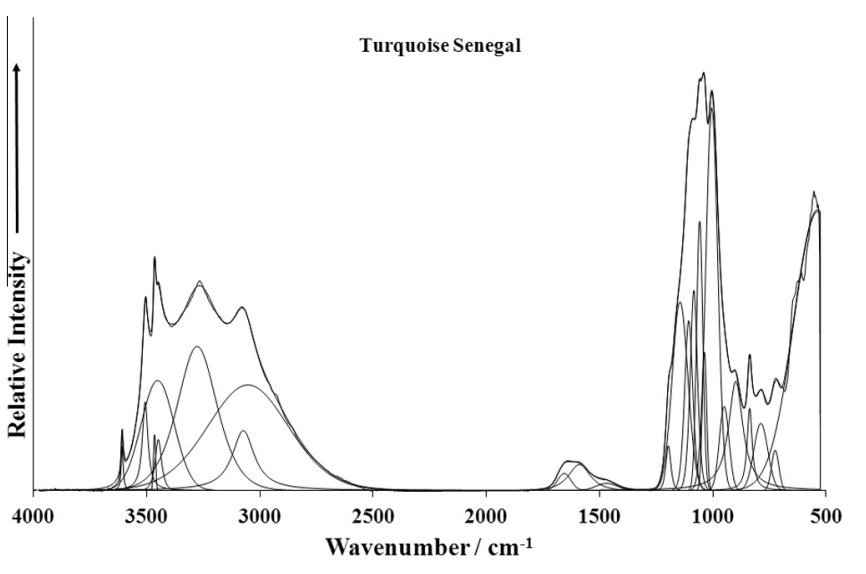

Fig. 4e. Infrared spectra of turquoise from Senegal over the $500-4000 \mathrm{~cm}^{-1}$ spectral range.

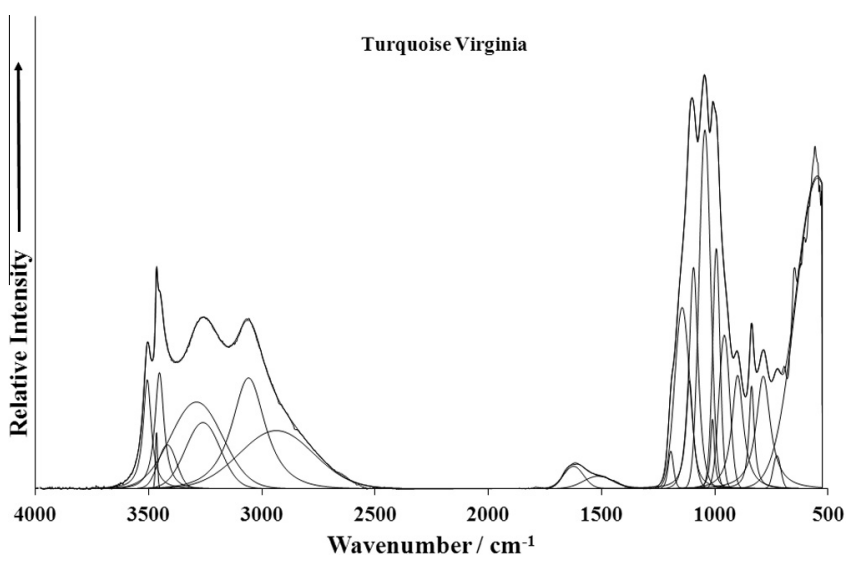

Fig. 4f. Infrared spectra of turquoise from Virginia over the $500-4000 \mathrm{~cm}^{-1}$ spectral range.

calculated using the Pearson VII profile shape function in the ZDS program package [43]. The measured patterns were indexed using unit-cell parameters and space group proposed by Kolitsch and Giester [42]. The unit-cell parameters refined from measured powder XRD using the program of Burnham [44] are compared with published data in the Table 1.

All turquoise samples were quantitatively analyzed by Cameca SX 100 electron microprobe system in wavelength dispersion mode for chemical composition (Table 2). Studied sample was mounted into the epoxide resin and polished. The polished surface was coated with carbon layer $250 \AA$. An acceleration voltage of $15 \mathrm{kV}$, a specimen current of $10 \mathrm{nA}$, and a beam diameter of $5 \mu \mathrm{m}$ were used. Well-defined natural and synthetic compounds were used as standards. The raw intensities were converted to the concentrations using automatic PAP matrix correction software package. On the basis of $\mathrm{P}+\mathrm{Si}=4 a p f u$, empirical formula of turquoise from Arizona may be expressed as $\left(\mathrm{Cu}_{0.90} \mathrm{Fe}_{0.10} \mathrm{Zn}_{0.01}\right)_{\Sigma 1.01} \mathrm{Al}_{6.08}$ $\left[\left(\mathrm{PO}_{4}\right)_{3.99}\left(\mathrm{SiO}_{4}\right)_{0.01}\right]_{\Sigma 4.00}(\mathrm{OH})_{8.24} \cdot 4 \mathrm{H}_{2} \mathrm{O}$; from Senegal as $\left(\mathrm{Cu}_{0.63} 0.29\right.$ $\left.\mathrm{Fe}_{0.05} \mathrm{Zn}_{0.02} \mathrm{Ba}_{0.01}\right)_{\Sigma 1.00}\left(\mathrm{Al}_{5.99} \mathrm{Fe}_{0.01}\right)_{\Sigma 6.00}\left[\left(\mathrm{PO}_{4}\right)_{3.71}\left(\mathrm{PO}_{3} \mathrm{OH}\right)_{0.29}\right]_{\Sigma 4.00}$ $(\mathrm{OH})_{7.71} \cdot 4 \mathrm{H}_{2} \mathrm{O}$ and from Virginia as $\left(\mathrm{Cu}_{1.03} \mathrm{Fe}_{0.11} \mathrm{Ba}_{0.02} \mathrm{Zn}_{0.01}\right.$ $\left.\mathrm{Ca}_{0.01}\right)_{\Sigma 1.18}\left(\mathrm{Al}_{5.84} \mathrm{Fe}_{0.16}\right)_{\Sigma 6.00}\left(\mathrm{PO}_{4}\right)_{4.00}(\mathrm{OH})_{8.36} \cdot 4 \mathrm{H}_{2} \mathrm{O}$.

\section{Raman and infrared spectroscopy}

Fragments of aggregates and crystals of turquoise were placed on a polished metal surface on the stage of an Olympus BHSM microscope, which is equipped with $10 \times, 20 \times$, and $50 \times$ objectives.
Table 3

Tentative assignment of turquoise spectra.

\begin{tabular}{|c|c|c|c|c|c|c|}
\hline \multicolumn{3}{|c|}{ Raman } & \multicolumn{3}{|c|}{ Infrared } & \multirow[t]{2}{*}{ Tentative assignment } \\
\hline A & $\mathrm{S}$ & $\mathrm{V}$ & A & $\mathrm{S}$ & $\mathrm{V}$ & \\
\hline 3544 & 3527 & & & 3607 & & \multirow{5}{*}{$v \mathrm{OH}$ stretch of $(\mathrm{OH})^{-}$} \\
\hline 3502 & 3506 & 3499 & 3509 & 3506 & 3505 & \\
\hline 3473 & 3471 & 3473 & 3465 & 3464 & 3465 & \\
\hline \multirow[t]{2}{*}{3450} & 3453 & 3451 & 3451 & 3450 & 3451 & \\
\hline & & & & 3447 & & \\
\hline 3397 & 3419 & 3410 & 3431 & & 3417 & \multirow{4}{*}{$v \mathrm{OH}$ stretch of water molecules } \\
\hline 3279 & 3290 & 3273 & 3269 & 3276 & 3288 & \\
\hline \multirow[t]{3}{*}{3077} & 3092 & 3085 & 3075 & 3072 & 3058 & \\
\hline & & & 3067 & 3051 & & \\
\hline & & 1632 & 1646 & 1654 & 1622 & \multirow{2}{*}{$\delta \mathrm{H}_{2} \mathrm{O}$ bend } \\
\hline \multirow[t]{2}{*}{1609} & 1614 & & 1595 & 1587 & & \\
\hline & & & 1474 & 1467 & 1513 & overtones of combination bands \\
\hline 1173 & 1184 & 1185 & 1195 & 1194 & 1192 & \multirow{4}{*}{$v_{3}\left(\mathrm{PO}_{4}\right)^{3-}$ antisymmetric stretch } \\
\hline 1160 & 1161 & 1162 & 1158 & 1143 & 1142 & \\
\hline \multirow[t]{2}{*}{1105} & 1104 & 1105 & 1103 & 1104 & 1110 & \\
\hline & & & 1084 & 1082 & 1092 & \\
\hline 1065 & 1064 & 1065 & 1055 & 1056 & & \multirow{2}{*}{$v_{1}\left(\mathrm{PO}_{4}\right)^{3-}$ symmetric stretch } \\
\hline \multirow[t]{2}{*}{1042} & 1041 & 1042 & & & 1042 & \\
\hline & 1031 & 1020 & 1034 & 1035 & & \multirow{6}{*}{$\delta \mathrm{Al}-\mathrm{OH}$ and $/ \mathrm{or} \delta \mathrm{Cu}-\mathrm{OH}$} \\
\hline 1004 & & & 1011 & 1002 & 1008 & \\
\hline 985 & 991 & 985 & 990 & & 991 & \\
\hline \multirow[t]{2}{*}{931} & 935 & 942 & 964 & 948 & 956 & \\
\hline & 836 & 889 & 899 & 897 & 897 & \\
\hline \multirow[t]{3}{*}{815} & 815 & 811 & 835 & 835 & 835 & \\
\hline & & & 785 & 786 & 784 & \\
\hline & & & 727 & 722 & 723 & libration modes od $\mathrm{H}_{2} \mathrm{O}$ \\
\hline & & 663 & & & & \\
\hline 643 & 642 & 644 & & & & \\
\hline & & 629 & & & & $v_{4}\left(\mathrm{PO}_{4}\right)^{3-}$ bend and/or \\
\hline & & 611 & & & & $\mathrm{Al}-(\mathrm{O}, \mathrm{OH})$ bend and/or \\
\hline 593 & 592 & 593 & & & & $\mathrm{Cu}-\mathrm{O}$ stretch \\
\hline 571 & 571 & 571 & & & & \\
\hline 550 & 548 & 551 & & & & \\
\hline 506 & 511 & 511 & & & & $v_{2}\left(\mathrm{PO}_{4}\right)^{3-}$ bend and/or \\
\hline & & 498 & & & & $\mathrm{Cu}-\mathrm{O}$ stretch and bend \\
\hline 485 & 483 & 486 & & & & \\
\hline 471 & 469 & 469 & & & & \\
\hline 457 & 460 & 449 & & & & \\
\hline 438 & 437 & 437 & & & & \\
\hline 426 & 423 & 425 & & & & \\
\hline 417 & 417 & 417 & & & & \\
\hline & & 408 & & & & \\
\hline 387 & 385 & 385 & & & & \\
\hline & & 367 & & & & \\
\hline 337 & 335 & 339 & & & & $\mathrm{Cu}-\left(\mathrm{O}, \mathrm{OH}, \mathrm{H}_{2} \mathrm{O}\right)$ and $\mathrm{Al}-\left(\mathrm{O}, \mathrm{OH}, \mathrm{H}_{2} \mathrm{O}\right)$ stretch and bend \\
\hline 321 & 320 & 319 & & & & vibrations (?) \\
\hline 303 & 301 & 303 & & & & \\
\hline 276 & 277 & & & & & \\
\hline 260 & 259 & 259 & & & & \\
\hline & & 252 & & & & \\
\hline 245 & 244 & 246 & & & & Jattice vibrations and/or \\
\hline 233 & 231 & 233 & & & & O-Cu-O hend and/or. \\
\hline 219 & 218 & 218 & & & & $\mathrm{O}-\mathrm{Cu}-\mathrm{O}$ bend and/or \\
\hline 211 & 210 & 212 & & & & O-Al-O bend \\
\hline 200 & 196 & 202 & & & & \\
\hline 176 & 175 & 177 & & & & \\
\hline 155 & 152 & 156 & & & & \\
\hline
\end{tabular}

The microscope is part of a Renishaw 1000 Raman microscope system, which also includes a monochromator, a filter system and a CCD detector (1024 pixels). The Raman spectra were excited by a Spectra-Physics model 127 He-Ne laser producing highly polarised light at $633 \mathrm{~nm}$ and collected at a nominal resolution of $2 \mathrm{~cm}^{-1}$ and a precision of $\pm 1 \mathrm{~cm}^{-1}$ in the range between 200 and $4000 \mathrm{~cm}^{-1}$. Repeated acquisition on the crystals using the highest magnification $(50 \times)$ were accumulated to improve the signal to noise ratio in the spectra. Spectra were calibrated using the $520.5 \mathrm{~cm}^{-1}$ line of a silicon wafer. Previous studies by the authors provide more 


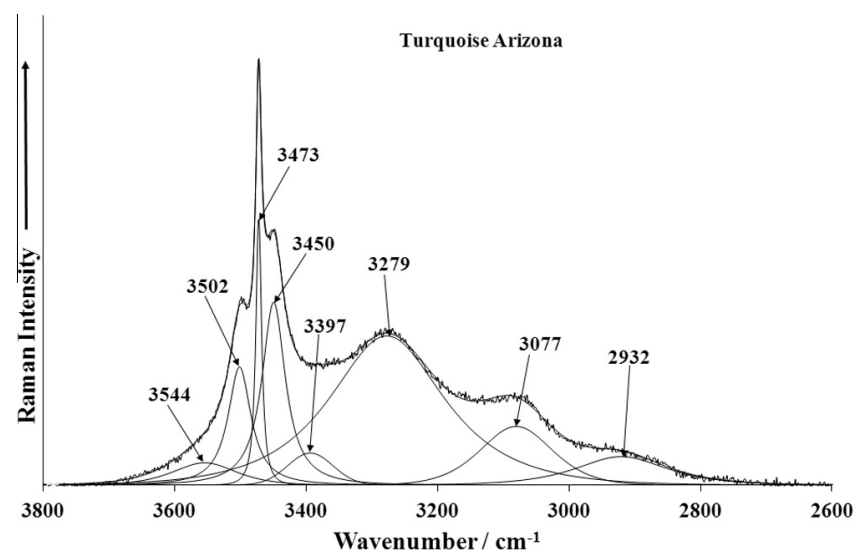

Fig. 5a. Raman spectrum of turquoise from Arizona over the $2600-3800 \mathrm{~cm}^{-1}$ spectral range.

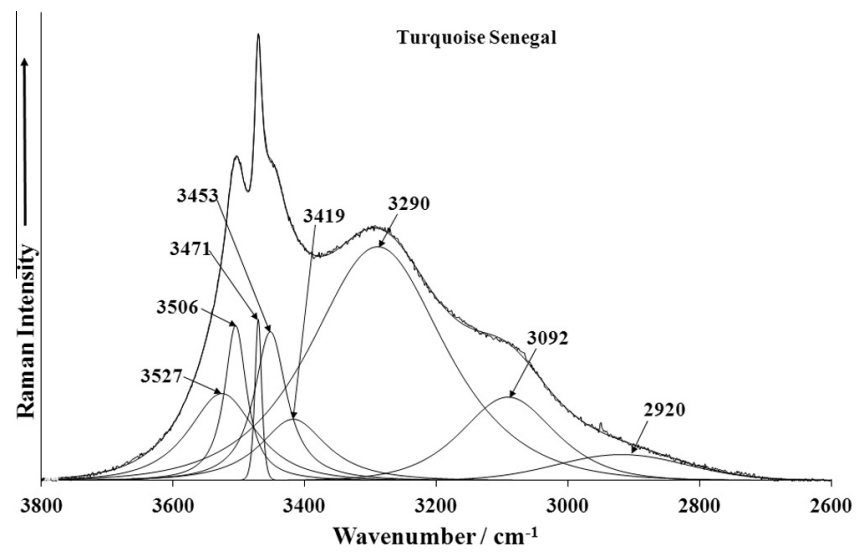

Fig. 5b. Raman spectrum of turquoise from Senegal over the $2600-3800 \mathrm{~cm}^{-1}$ spectral range.

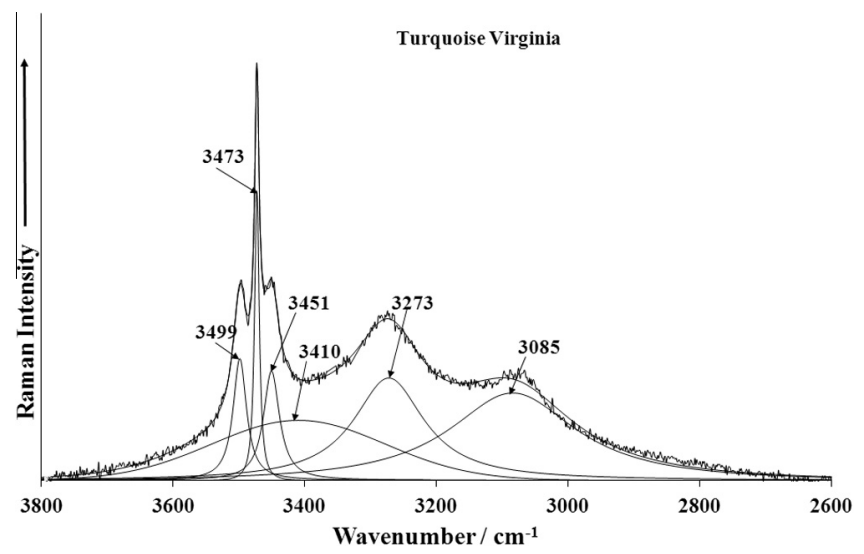

Fig. 5c. Raman spectrum of turquoise from Virginia over the $2600-3800 \mathrm{~cm}^{-1}$ spectral range.

details of the experimental technique. Alignment of all samples in a similar orientation has been attempted and achieved. However, differences in intensity may be observed due to minor differences in the crystal orientation.

Infrared spectra was recorded by micro diffuse reflectance method (DRIFTS) on a Nicolet Magna 760 FTIR spectrometer (range $4000-600 \mathrm{~cm}^{-1}$, resolution $4 \mathrm{~cm}^{-1}, 128$ scans, 2 level zero-filtering, Happ-Genzel apodization), equipped with Spectra Tech InspectIR

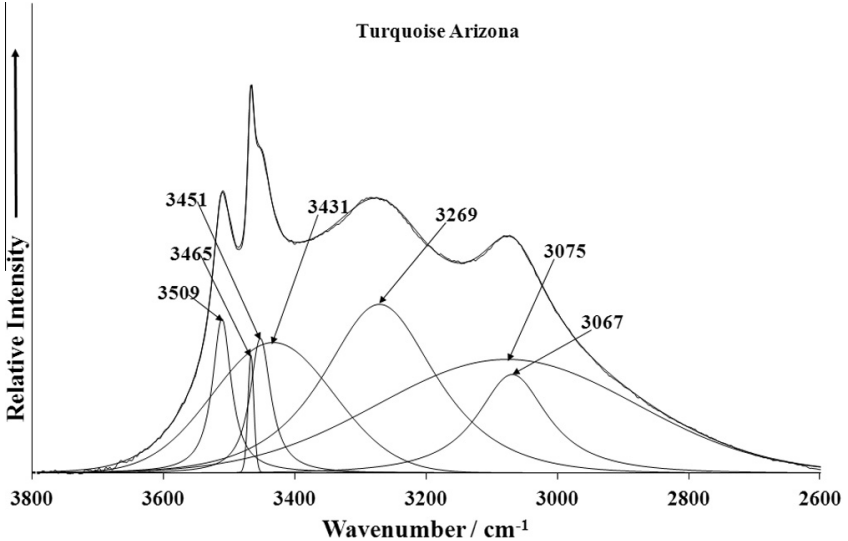

Fig. 5d. Infrared spectrum of turquoise from Arizona over the $2600-3800 \mathrm{~cm}^{-1}$ range.

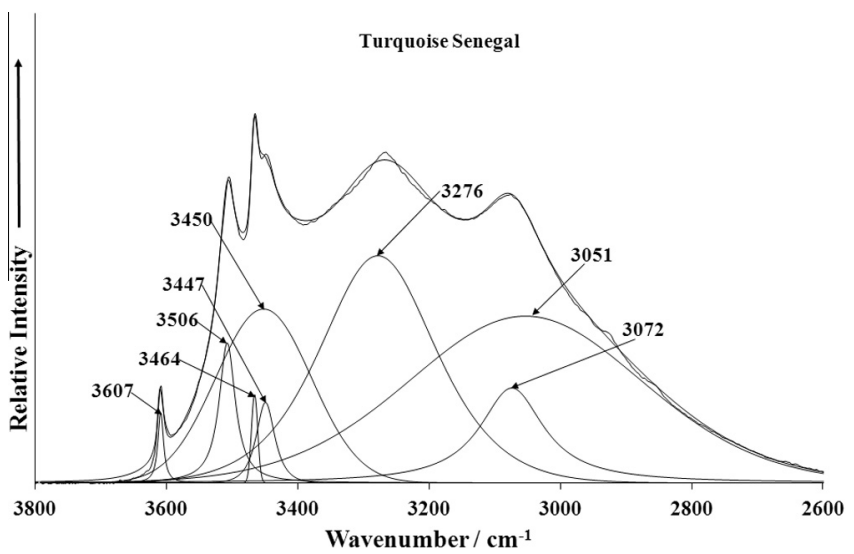

Fig. 5e. Infrared spectrum of turquoise from Senegal over the $2600-3800 \mathrm{~cm}^{-1}$ range.

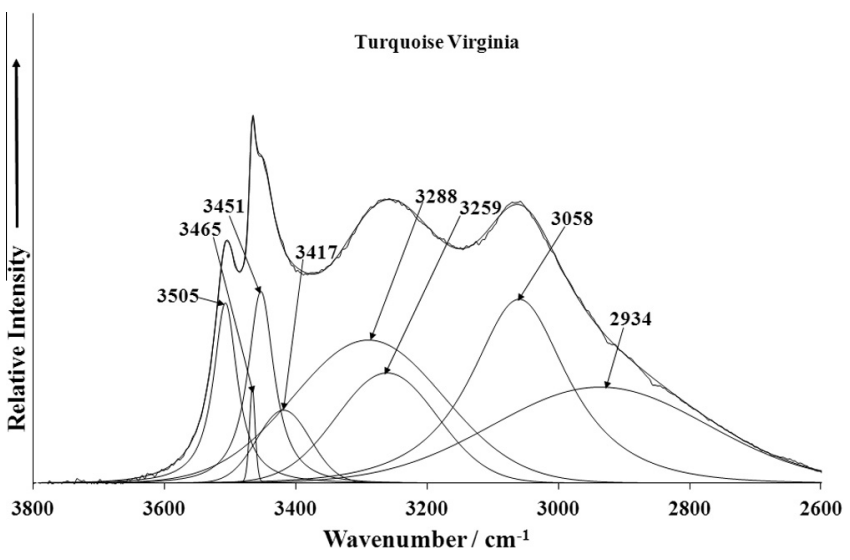

Fig. 5f. Infrared spectrum of turquoise from Virginia over the $2600-3800 \mathrm{~cm}^{-1}$ range.

micro FTIR accessory. Sample of amount less than $0.050 \mathrm{mg}$ was mixed without using pressure with $\mathrm{KBr}$. Samples were immediately recorded together with the same $\mathrm{KBr}$ as a reference.

Spectral manipulation such as baseline correction/adjustment and smoothing were performed using the Spectracalc software package GRAMS (Galactic Industries Corporation, NH, USA). Band component analysis was undertaken using the Jandel 'Peakfit' software package that enabled the type of fitting function to be 
selected and allows specific parameters to be fixed or varied accordingly. Band fitting was done using a Lorentzian-Gaussian cross-product function with the minimum number of component bands used for the fitting process. The Lorentzian-Gaussian ratio was maintained at values greater than 0.7 and fitting was undertaken until reproducible results were obtained with squared correlations of $r^{2}$ greater than 0.995 .

\section{Results and discussion}

\section{Crystal symmetry and vibrational spectra of turquoise}

Turquoise, $\mathrm{CuAl}_{6}\left(\mathrm{PO}_{4}\right)_{4}(\mathrm{OH})_{8} \cdot 4 \mathrm{H}_{2} \mathrm{O}$, is triclinic, space group $P-1$ - $C_{i}{ }^{1}, Z=1$. The structure consists of distorted $\mathrm{CuO}_{6}$ polyhedra, $\mathrm{AlO}_{6}$ octahedra and $\mathrm{PO}_{4}$ tetrahedra. By edge- and corner-sharing of these polyhedra a fairly dense three-dimensional framework is formed which is further strengthened by a system of hydrogen bonds [42].

In the crystal structure of turquoise there are one symmetrically distinct $\mathrm{CuO}_{6}$ octahedron, three structurally distinct $\mathrm{AlO}_{6}$ octahedra, two symmetrically distinct $\mathrm{PO}_{4}$ tetrahedra, two structurally unequivalent water molecules and four structurally unequivalent $\mathrm{OH}$ units $[41,42]$. Tentative interpretation of infrared and Raman spectra of turquoise studied is based on factor group analysis of phosphates and water in turquoise published by Frost et al. [13] and publications by Nakamoto [45], Čejka et al. [35], Keller [4649], Pechkovskii et al. [50], Goldsmith and Ross [51], Devamani and Alagar [52], Aguirre et al. [53], Frost et al. [13,54] and Reddy et al. [14].

According to Nakamoto [45], octahedral units $\mathrm{XY}_{6}$ exhibit six normal vibrations, from which $v_{1}\left(A_{1 \mathrm{~g}}\right)$ and $v_{2}\left(E_{\mathrm{g}}\right)$ stretching and $v_{5}\left(F_{2 \mathrm{~g}}\right)$ bending vibrations are Raman active, while only $v_{3}\left(F_{1 \mathrm{u}}\right)$ stretching and $v_{4}\left(F_{1 \mathrm{u}}\right)$ bending vibrations are infrared active. Symmetry lowering in the case of $\mathrm{XY}_{4} \mathrm{Z}_{2}$ may cause Raman and infrared activation of corresponding vibrations and also splitting of degenerate vibrations. Free $\left(\mathrm{PO}_{4}\right)^{3-}$ anion exhibits tetrahedral $T_{\mathrm{d}}$ symmetry. In the case of a free ion of $T_{\mathrm{d}}$ symmetry, there are 9 normal vibrations characterized by four distinguishable modes of vibrations: $v_{1}\left(A_{1}\right)$ symmetric stretching vibration, Raman active, $v_{2}(\delta)(E)$ doubly degenerate bending vibration, Raman active, $v_{3}$ $\left(F_{2}\right)$ triply degenerate antisymmetric stretching vibration, Raman and infrared active, $v_{4}(\delta)\left(F_{2}\right)$ triply degenerate bending vibration, Raman and infrared active. $T_{\mathrm{d}}$ symmetry lowering may cause infrared activation of the $v_{1}$ and $v_{2}$ vibrations and splitting of the doubly degenerate $v_{2}$ and triply degenerate $v_{3}$ and $v_{4}$ vibrations [35].

\section{Raman and infrared spectroscopy}

Full range Raman and infrared spectra of the studied minerals from Arizona (A), Senegal (S) and Virginia (V) are given in Figs. $4 \mathrm{a}-\mathrm{f}$ and their tentative assignments in Table 3 . These spectra show the position of the bands and their relative intensities. It is obvious that there are large parts of the spectra where little or no intensity is observed. Therefore, the spectra are subdivided into sections according to the type of vibration is being investigated. In this way the precise position of the bands can be detailed. Observed wavenumbers of the Raman bands of the studied turquoise samples are close to the approximate wavenumbers inferred from the Raman spectra of RRUFF's three turquois samples R50225, R50418 and R50554.

Raman and infrared spectral regions of $v \mathrm{OH}$ stretching vibrations are presented in Figs. 5a-f. Raman bands et 3544, 3502, 3473 and $3450 \mathrm{~cm}^{-1}$ (A), 3527, 3506, 3471 and $3453 \mathrm{~cm}^{-1}$ (S) and 3499,3473 and $3451 \mathrm{~cm}^{-1}(\mathrm{~V})$ and infrared bands at 3509 , 3465 and $3451 \mathrm{~cm}^{-1}$ (A), 3607, 3506, 3464, 3450 and $3447 \mathrm{~cm}^{-1}$

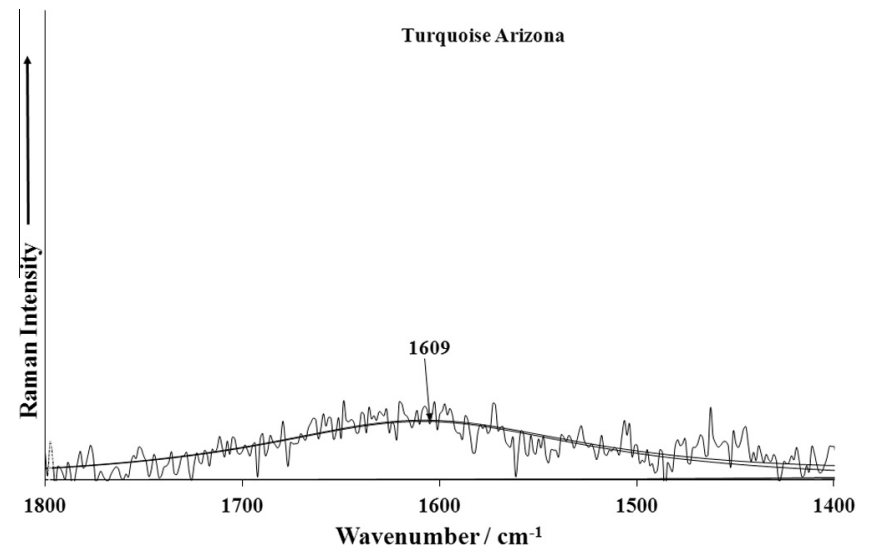

Fig. 6a. Raman spectrum of turquoise from Arizona over the $1400-1800 \mathrm{~cm}^{-1}$ spectral range.

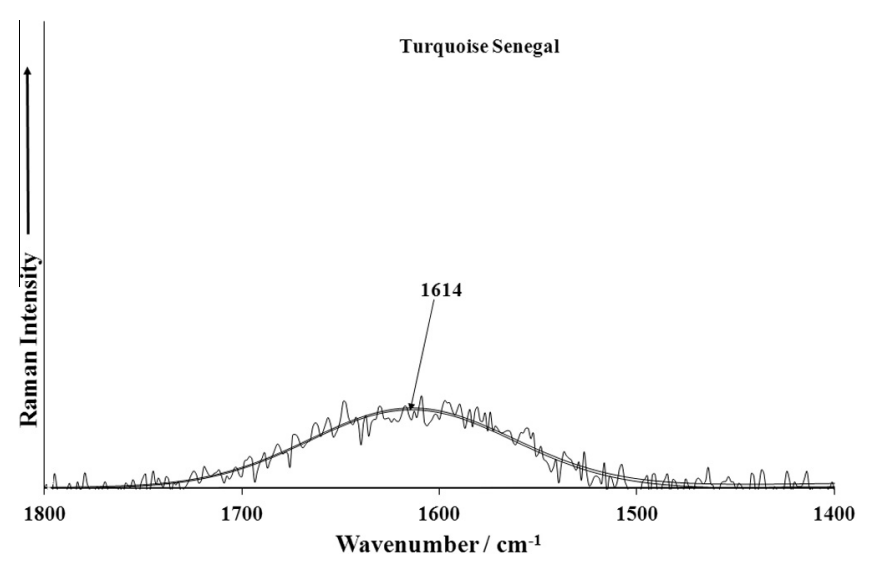

Fig. 6b. Raman spectrum of turquoise from Senegal over the $1400-1800 \mathrm{~cm}^{-1}$ spectral range.

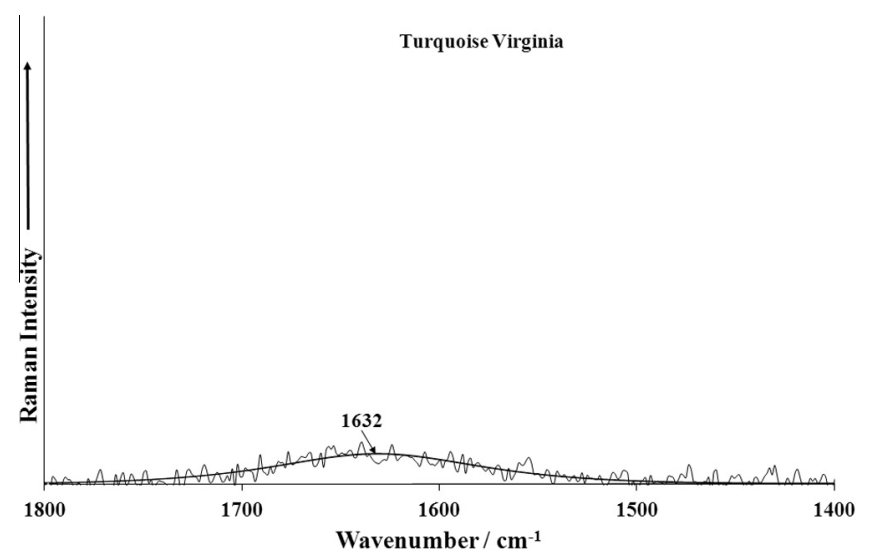

Fig. 6c. Raman spectrum of turquoise from Virginia over the $1400-1800 \mathrm{~cm}^{-1}$ range.

(S) and 3505, 3465 and $3451 \mathrm{~cm}^{-1}(\mathrm{~V})$ are assigned to the $v \mathrm{OH}$ stretching vibrations and assigned to the hydrogen bonded, symmetrically distinct hydroxyls $\mathrm{OH}^{-}$. Raman bands at 3397, 3279 and $3077 \mathrm{~cm}^{-1}$ (A), 3419, 3290 and $3092 \mathrm{~cm}^{-1}$ (S), 3410, 3273 and $3085 \mathrm{~cm}^{-1}(\mathrm{~V})$, and infrared spectra at 3431, 3269, 3075 and $3067 \mathrm{~cm}^{-1}$ (A), 3276, 3072 and $3051 \mathrm{~cm}^{-1}$ (S) and 3417, 3288 and $3058 \mathrm{~cm}^{-1}(\mathrm{~V})$ are attributed to the $v \mathrm{OH}$ stretching vibrations of symmetrically distinct hydrogen bonded water molecules. Very 


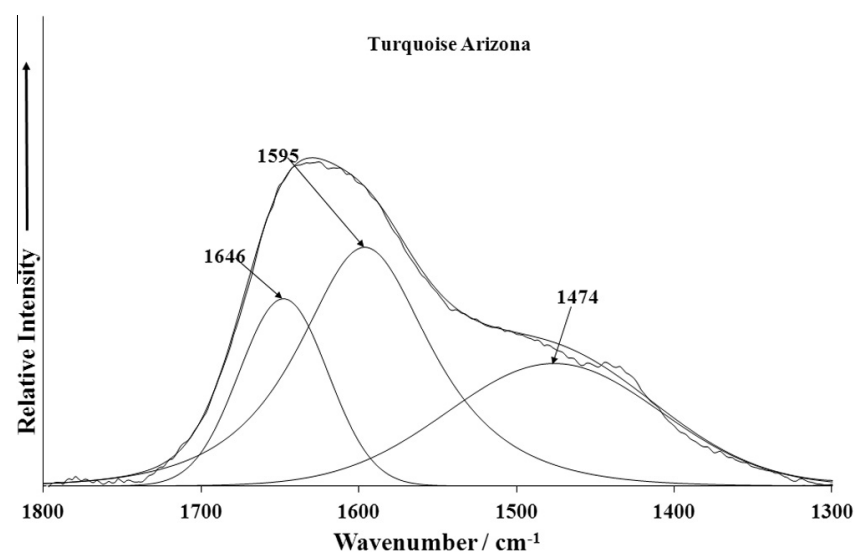

Fig. 6d. Infrared spectrum of turquoise from Arizona over the $1300-1800 \mathrm{~cm}^{-1}$ range.

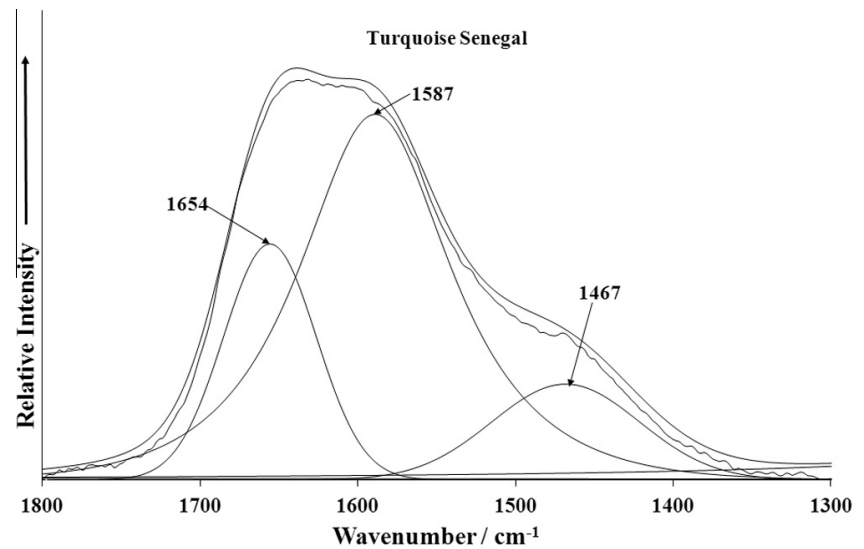

Fig. 6e. Infrared spectrum of turquoise from Senegal over the $1300-1800 \mathrm{~cm}^{-1}$ range.

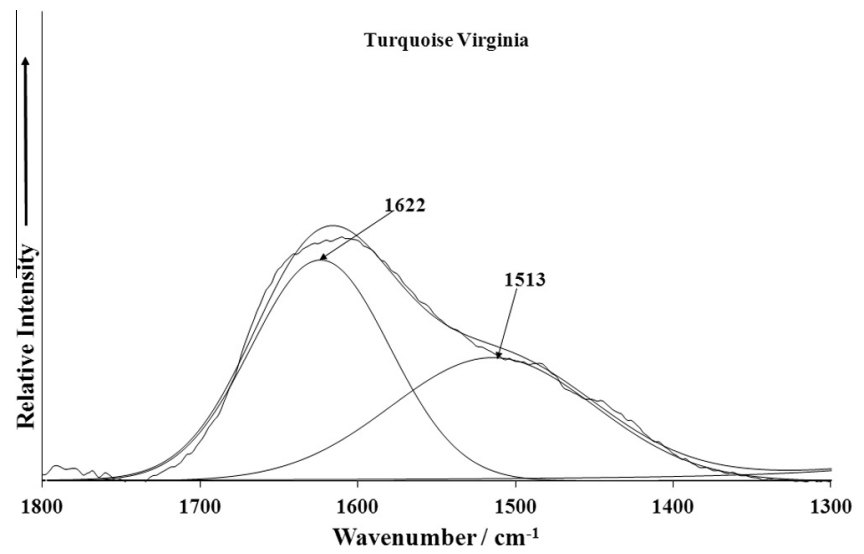

Fig. 6f. Infrared spectrum of turquoise from Virginia over the $1450-1750 \mathrm{~cm}^{-1}$ range.

weak Raman and infrared bands at 2932, 2920 and $2934 \mathrm{~cm}^{-1}$ are probably connected with organic impurities.

Libowitzky's empirical relation [55] enables to infer from the wavenumbers of Raman and infrared bands of minerals assigned to the $v \mathrm{OH}$ stretching vibrations approximate $\mathrm{O}-\mathrm{H} \cdots \mathrm{O}$ hydrogen bond lengths. In the case of studied turquoise samples inferred hydrogen bond lengths vary from 2.98 to $2.67 \AA$. This agrees very

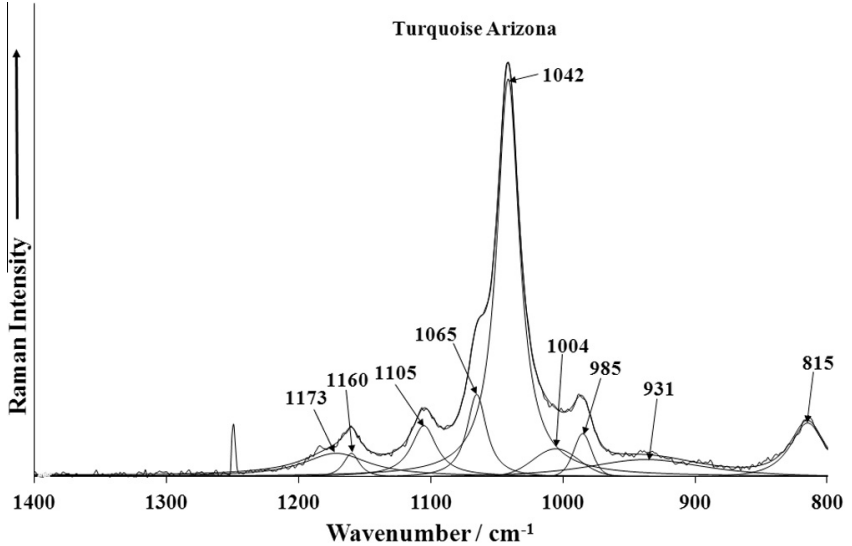

Fig. 7a. Raman spectrum of turquoise from Arizona over the $800-1400 \mathrm{~cm}^{-1}$ range.

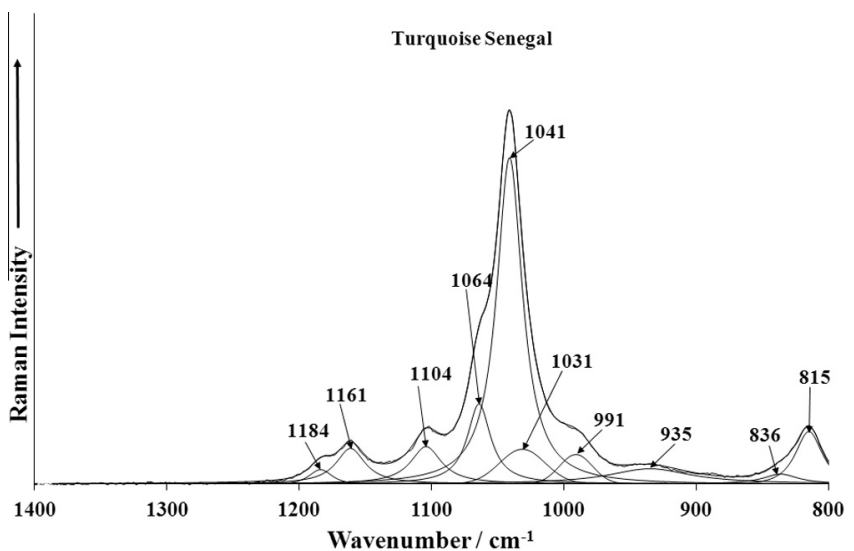

Fig. 7b. Raman spectrum of turquoise from Senegal over the $800-1400 \mathrm{~cm}^{-1}$ range.

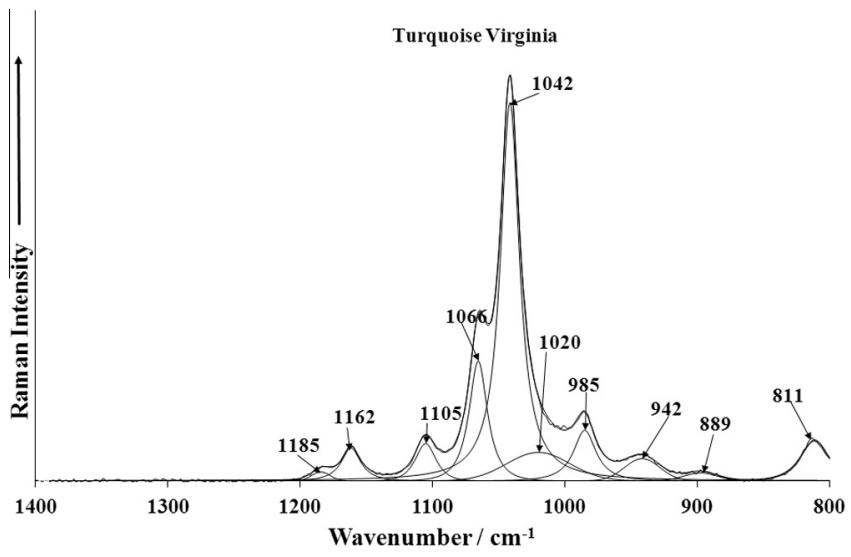

Fig. 7c. Raman spectrum of turquoise from Virginia over the $800-1400 \mathrm{~cm}^{-1}$ range.

well with X-ray single crystal structure data 2.970-2.670 $\AA$ [41] and 3.020-2.685 А̊ [42].

Broad Raman bands at $1609 \mathrm{~cm}^{-1}$ (A), $1614 \mathrm{~cm}^{-1}$ (S) and $1632 \mathrm{~cm}^{-1}(\mathrm{~V})$ and infrared bands at 1646 and $1595 \mathrm{~cm}^{-1}(\mathrm{~A})$, 1654 and $1587 \mathrm{~cm}^{-1}(\mathrm{~S})$ and $1622 \mathrm{~cm}^{-1}(\mathrm{~V})$ are attributed to the $v_{2}(\delta) \mathrm{H}_{2} \mathrm{O}$ bending vibrations of the symmetrically distinct differently hydrogen bonded water molecules (Figs. 6a-f). Observed infrared bands at $1474 \mathrm{~cm}^{-1}(\mathrm{~A}), 1467 \mathrm{~cm}^{-1}$ (S) and $1513 \mathrm{~cm}^{-1}$ $(\mathrm{V})$ are assigned to overtones or combination bands. 


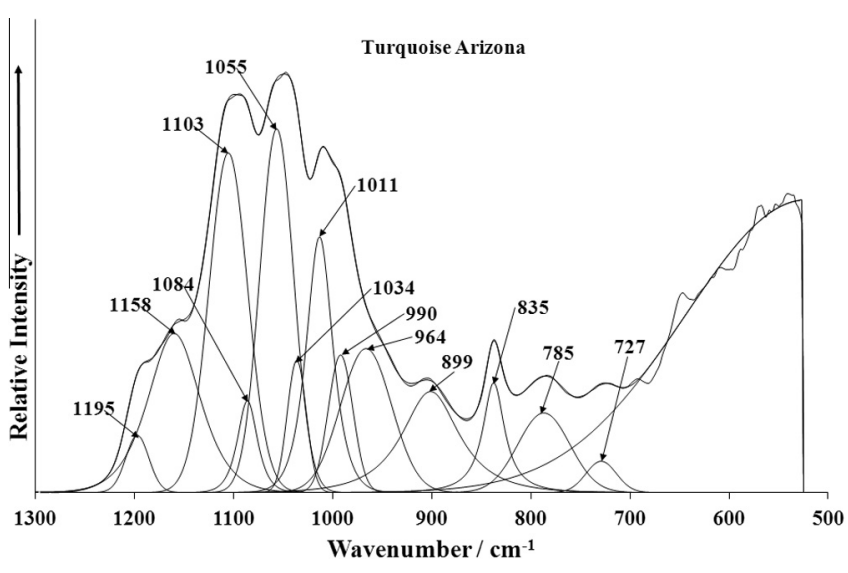

Fig. 7d. Infrared spectrum of turquoise from Arizona over the $500-1300 \mathrm{~cm}^{-1}$ range.

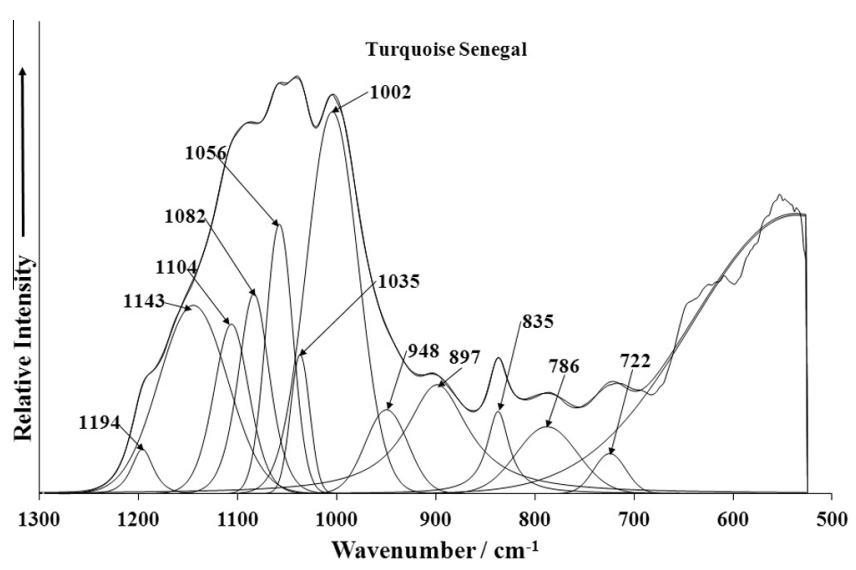

Fig. 7e. Infrared spectrum of turquoise from Arizona over the $500-1300 \mathrm{~cm}^{-1}$ range.

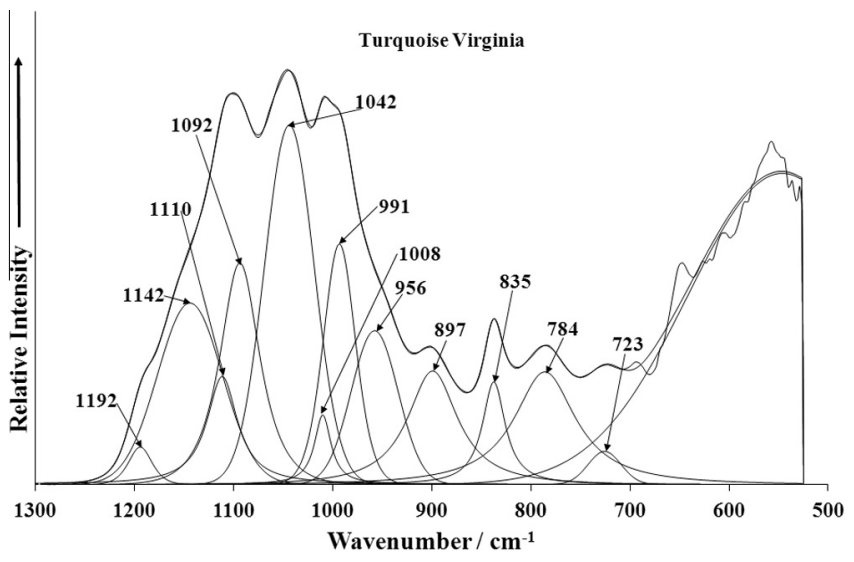

Fig. 7f. Infrared spectrum of turquoise from Virginia over the $500-1300 \mathrm{~cm}^{-1}$ range.

The Raman spectra in the $800-1400 \mathrm{~cm}^{-1}$ spectral range and infrared spectra in the $500-1300 \mathrm{~cm}^{-1}$ spectral range are reported in Figs. 7a-f. Raman bands at 1173, 1160 and $1105 \mathrm{~cm}^{-1}$ (A), 1184, 1161 and $1104 \mathrm{~cm}^{-1}(\mathrm{~S})$, and 1185,1162 and $1105 \mathrm{~cm}^{-1}(\mathrm{~V})$ and infrared bands and shoulders at 1195, 1158, 1103 and $1084 \mathrm{~cm}^{-1}$ (A), 1194, 1143, 1104 and $1082 \mathrm{~cm}^{-1}$ (S), and 1192, 1142, 1110 and $1092 \mathrm{~cm}^{-1}(\mathrm{~V})$ are connected with split triply degenerate $v_{3}$ $\left(\mathrm{PO}_{4}\right)^{3-}$ antisymmetric stretching vibrations.

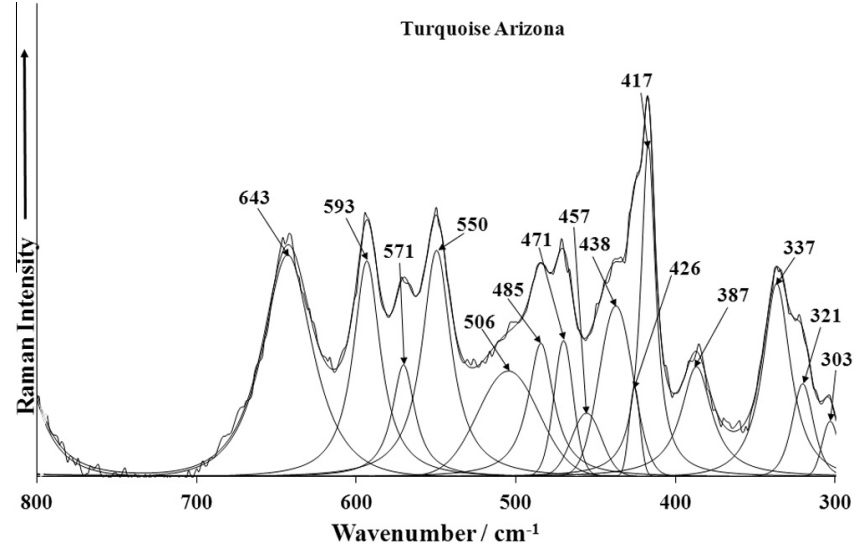

Fig. 8a. Raman spectrum of turquoise from Arizona over the $300-800 \mathrm{~cm}^{-1}$ range

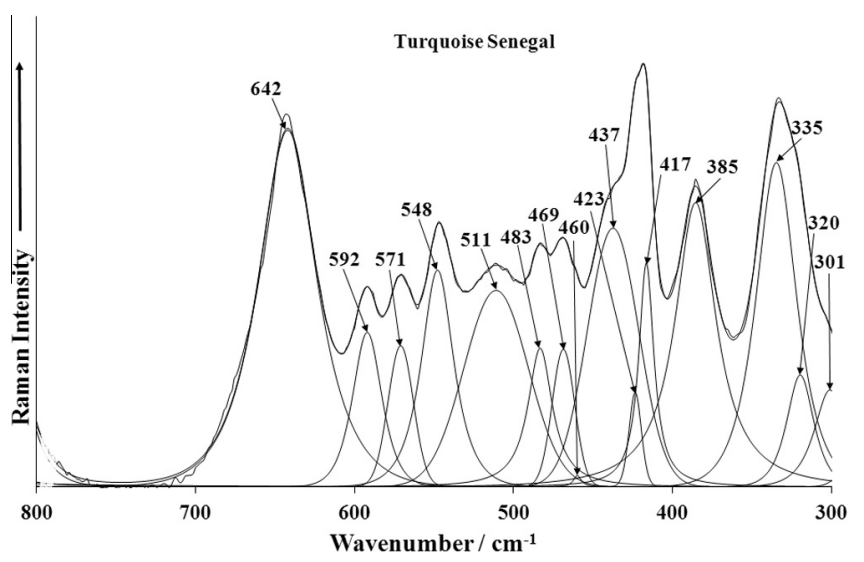

Fig. 8b. Raman spectrum of turquoise from Senegal over the $300-800 \mathrm{~cm}^{-1}$ range.

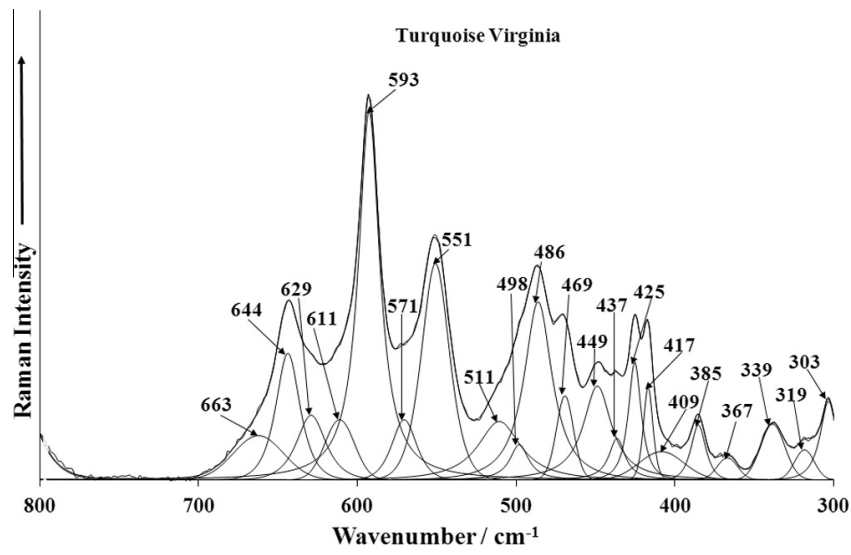

Fig. 8c. Raman spectrum of turquoise from Virginia over the $300-800 \mathrm{~cm}^{-1}$ range.

Very intense Raman bands at $1042 \mathrm{~cm}^{-1}$ (A), $1041 \mathrm{~cm}^{-1}$ (S), $1042 \mathrm{~cm}^{-1}(\mathrm{~V})$ and infrared bands at $1055 \mathrm{~cm}^{-1}(\mathrm{~A}), 1056 \mathrm{~cm}^{-1}$ $(\mathrm{S}), 1042 \mathrm{~cm}^{-1}(\mathrm{~V})$ are assigned to the $\mathrm{v}_{1}\left(\mathrm{PO}_{4}\right)^{3-}$ symmetric stretching vibrations. Raman bands at $1065 \mathrm{~cm}^{-1}(\mathrm{~A}), 1064 \mathrm{~cm}^{-1}(\mathrm{~S})$ and $1065 \mathrm{~cm}^{-1}(\mathrm{~V})$ are also related to the $v_{1}\left(\mathrm{PO}_{4}\right)^{3-}$ vibrations. Some of the Raman bands and shoulders at 1004, 985 and $931 \mathrm{~cm}^{-1}(\mathrm{~A})$, $1031,991,935 \mathrm{~cm}^{-1}(\mathrm{~S}), 1020,985,942,889 \mathrm{~cm}^{-1}(\mathrm{~V})$ and infrared bands and shoulders 1034, 1011, 990, 964, $899 \mathrm{~cm}^{-1}$ (A), 1035, $1002,948,897 \mathrm{~cm}^{-1}(\mathrm{~S}), 1008,991,956,897 \mathrm{~cm}^{-1}$ (V) may also be related to these vibrations, however more probably may be 


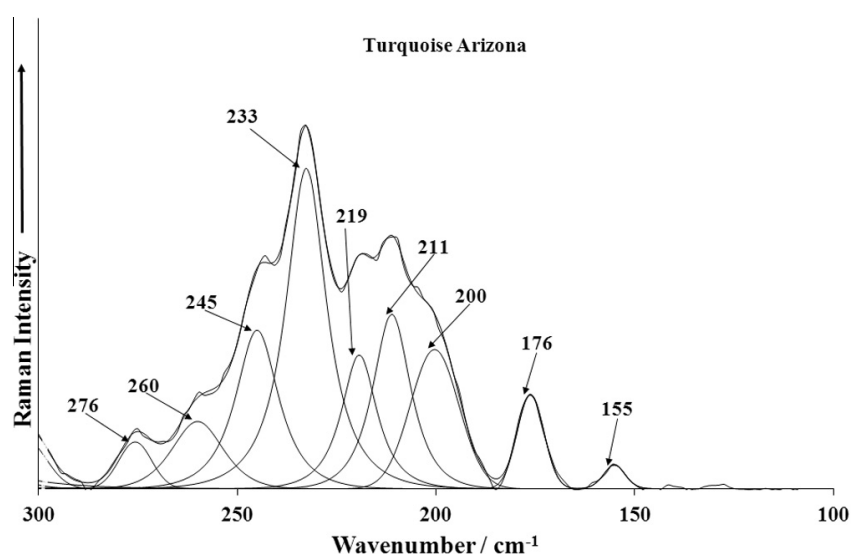

Fig. 9a. Raman spectrum of turquoise from Arizona over the $100-300 \mathrm{~cm}^{-1}$ range.

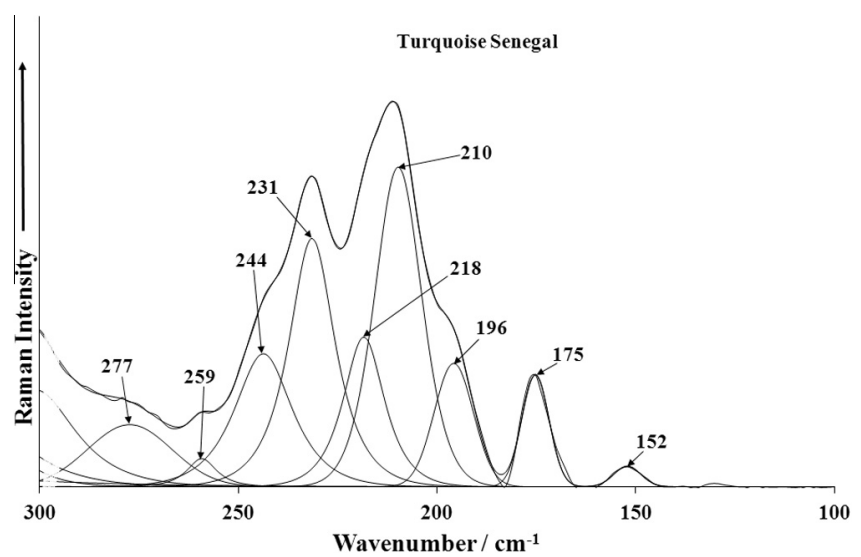

Fig. 9b. Raman spectrum of turquoise from Senegal over the $100-300 \mathrm{~cm}^{-1}$ range.

attributed to the $\delta \mathrm{Al}-\mathrm{OH}$ and $\delta \mathrm{Cu}-\mathrm{OH}$ bending vibrations together with the Raman bands at $815 \mathrm{~cm}^{-1}(\mathrm{~A}), 836$ and $815 \mathrm{~cm}^{-1}(\mathrm{~S})$, $811 \mathrm{~cm}^{-1}(\mathrm{~V})$ and infrared bands at $835 \mathrm{~cm}^{-1}(\mathrm{~A}), 835 \mathrm{~cm}^{-1}$ (S), $835 \mathrm{~cm}^{-1}(\mathrm{~V})$, while the infrared bands at 785 and $727 \mathrm{~cm}^{-1}(\mathrm{~A})$, 786 and $722 \mathrm{~cm}^{-1}(\mathrm{~S}), 784,723 \mathrm{~cm}^{-1}(\mathrm{~V})$ are assigned to the librational modes of water molecules.

Because the character of the Raman spectra of all three studied turquoise samples in the region from 1200 to $900 \mathrm{~cm}^{-1}$ is practically identical, it is very improbable that in the structure of the turquoise sample from Senegal could be present the $\left(\mathrm{PO}_{3} \mathrm{OH}\right)^{2-}$ units, as expected from the mechanism of planerite substitution proposed by Foord and Taggart [36]. More distinctive is therefore the explanation of vacancy given by Kolitsch and Giester [42].

The Raman spectra of turquoise in the $300-800 \mathrm{~cm}^{-1}$ spectral range are displayed in Figs. $8 \mathrm{a}-\mathrm{c}$. Raman bands and shoulders at $643,593,571$ and $550 \mathrm{~cm}^{-1}(\mathrm{~A}), 642,592,571$ and $548 \mathrm{~cm}^{-1}(\mathrm{~S})$, $663,644,629,611,593,571$ and $551 \mathrm{~cm}^{-1}(\mathrm{~V})$ are assigned to the split out-of-plane triply degenerate $v_{4}(\delta)\left(\mathrm{PO}_{4}\right)^{3-}$ bending vibrations. Some of observed bands, however, may be also connected with the $\mathrm{Al}(\mathrm{O}, \mathrm{OH})$ bending vibrations and $\mathrm{Cu}-\mathrm{O}$ stretching vibrations. Coincidence (an overlap) of the mentioned vibrations is supposed. Raman bands and shoulders at 506, 485, 471, 457, 438, 426, 417 and $387 \mathrm{~cm}^{-1}$ (A), 511, 483, 469, 460, 437, 423, 417 and $385 \mathrm{~cm}^{-1}$ (S), 511, 498, 486, 469, 449, 437, 425, 417, 409 and $385 \mathrm{~cm}^{-1}(\mathrm{~V})$ are related to the split doubly degenerate $v_{2}(\delta)$ $\left(\mathrm{PO}_{4}\right)^{3-}$ bending vibrations. These bands may partly overlap with bands of $\mathrm{Cu}-\mathrm{O}$ stretching vibrations and bending vibrations.

Raman bands at 337, 321 and $303 \mathrm{~cm}^{-1}$ (A), 335, 320 and $301 \mathrm{~cm}^{-1}(\mathrm{~S}), 367,339,319$ and $303 \mathrm{~cm}^{-1}(\mathrm{~V})$. - these bands may

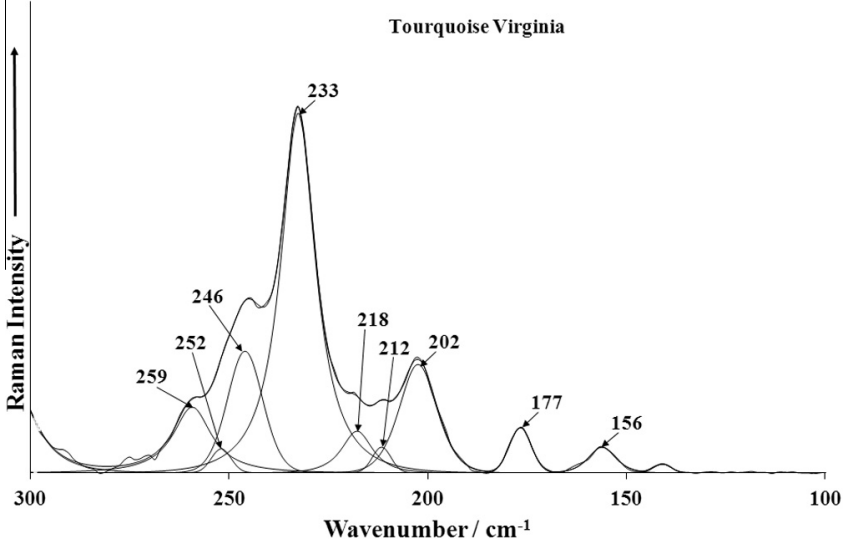

Fig. 9c. Raman spectrum of turquoise from Virginia over the $100-300 \mathrm{~cm}^{-1}$ range.

probably be related to the stretching and bending vibrations of $\mathrm{Cu}-\left(\mathrm{O}, \mathrm{OH}, \mathrm{H}_{2} \mathrm{O}\right)$ and $\mathrm{Al}-\left(\mathrm{O}, \mathrm{OH}, \mathrm{H}_{2} \mathrm{O}\right)$. Raman bands observed in the region from 300 to $100 \mathrm{~cm}^{-1}$ (Figs. 9a-c) may be assigned to OCuO bending vibrations, OAlO bending vibrations and lattice vibrations.

\section{Conclusions}

1. Raman and infrared spectra of three well defined turquoise samples were recorded.

2. Observed Raman and infrared bands are tentatively interpreted and assigned to the stretching and bending vibrations of $\left(\mathrm{PO}_{4}\right)^{3-}$ tetrahedra and of vibrations of hydrogen bonded water molecules and hydroxyl ions. No Raman and infrared bands which could be unambiguously attributed to the stretching and bending vibrations $\left(\mathrm{PO}_{3} \mathrm{OH}\right)^{2-}$ were observed.

3. Approximate $\mathrm{O}-\mathrm{H} \ldots \mathrm{O}$ hydrogen bond lengths are inferred from observed Raman and infrared bands connected with the $v \mathrm{OH}$ stretching vibrations of water molecules and hydroxyl ions.

4. Observed Raman and infrared spectra of studied turquoise samples are very similar and comparable. From the results may be inferred that Raman spectroscopy may be very well used to distinguish natural turquoise samples from possible imitations including impregnations of natural material. Vibrational spectra of natural turquoise samples from various localities possessing different morphology, colors etc. are very close. Vibrational spectroscopy cannot be therefore offer reliable data for the provenance determination of natural turquoise.

\section{Acknowledgements}

The financial and infra-structure support of the Discipline of Nanotechnology and Molecular Science, Science and Engineering Faculty of the Queensland University of Technology, is gratefully acknowledged. The Australian Research Council (ARC) is thanked for funding the instrumentation. This work was financially supported by the long-term project DKRVO 2014/02-2015/02 of the Ministry of Culture of the Czech Republic (National Museum, 00023272). The downloading of the Raman spectra of turquoise from the RRUFF web site is acknowledged.

\section{References}

[1] O.T. Branson, Turquoise, the Gem of the Centuries, Treasure Chest Publication, Tucson, Arizona, 1975. 62 pp.

[2] E. Fritsch, S.F. McClure, M. Ostrooumov, Y. Andres, T. Moses, J.I. Koivula, R.C. Kammerling, Gems Gemol. 35 (1999) 4-16. 
[3] S. Hull, M. Fayek, F.J. Mathien, P. Shelley, K. Roler Durand, J. Archaeological Sci. 35 (2008) 1355-1369.

[4] Y.A. Abdu, S.K. Hull, M. Fayek, F.C. Hawthorne, Am. Miner. 96 (2011) 14331442.

[5] Q. Chen, L. Oi, J. Chen, Spectrosc. Spectral Anal. 29 (2009) 406-409.

[6] L. She, Y. Qin, M. Feng, Z. Mao, C. Xu, F. Huang, Guang pu 28 (2008) 2107-2110.

[7] Q. Chen, Z. Yin, L. Qi, Y. Xiong, Gems Gemol. 48 (2012) 198-204.

8] Q. Chen, L. Qi, J. Miner. Petrol. 27 (2007) 30-35.

[9] Z. Jiang, D. Chen, W. Wang, W. Li, X. Cao, Q. Wu, Acta Miner. Sin. (1983) 198206.

[10] X.A. Li, Y.F. Wang, H.F. Zhang, Acta Miner. Sin. (1984) 78-83.

[11] L.J. Luan, Z.X. Han, C.Y. Wang, Y.W. Zhang, Northwestern Geol. 37 (2004) 7782.

[12] H.F. Zhang, C.Y. Lin, Z.W. Ma, Z.G. Yang, Acta Miner. Sin. (1982) 254-261.

[13] R.L. Frost, B.J. Reddy, W.N. Martens, M. Weier, J. Mol. Struct. 788 (2006) 224231.

[14] B.J. Reddy, R.L. Frost, M.L. Weier, W.N. Martens, J. Near Infrared Spectrosc. 14 (2006) 241-250.

[15] H. Pristacz, M. Wildner, R. Škoda, F. Koller, E. Libowitzky, EMC2012 -European Mineralogical Conference, 1 (2012) 461.

[16] B. Cervelle, La Rech. 163 (1985) 244-247.

[17] R.T. Liddicoat Jr., Handbook of Gem Identification, 12th ed., Gemological Institute of America, Santa Monica, California, 1989.

[18] Q. Chen, L. Qi, Y. Zhang, J. Gems Gemol. (2006) 9-12.

[19] K.S. Moe, T.M. Moses, P. Johnson, Gems Gemol. 43 (2007) 149-151.

[20] A. Pavese, L. Prosperi, M. Dapiaggi, Austr. Gemol. 22 (2005) 366-371.

[21] J. Zhou, X. Yuan, J. Gems Gemol. (2008) 31-35.

[22] D. Elwell, Man-made Gemstones, John Wiley Sons, New York, 1979.

[23] J.D. Williams, D. Nassau, Gems Gemol. 15 (1976) 226-232.

[24] H. Pristacz, M. Wildner, V.M.F. Hammer, E. Libowitzky, Corals-2013, Conference on Raman and Luminiscence Spectroscopy in the Earth Sciences, 2013, 81-82.

[25] J. Sejkora, T. Řídkošil, V. Šrein, N. Jb. Miner. Abh. 175 (1999) 105-124.

[26] J. Sejkora, F.C. Hawthorne, M.A. Cooper, J.D. Grice, J. Vajdak, J.L. Jambor, Can. Miner. 47 (2009) 159-164.

[27] J. Sejkora, J. Plášil, B. Bureš, Bull. Miner. Petrol. Odd. Nár. Muz. (Praha) 21 (2013) 143-156 (in Czech).

[28] J. Sejkora, P. Škácha, V. Venclík, J. Plášil, Bull. Miner. Petrol. Odd. Nár. Muz. (Praha) 21 (2013) 113-130 (in Czech).

[29] L. Vrtiška, J. Sejkora, H. Nováková, M. Vašinová Galiová, Bull. Miner. Petrol. Odd. Nár. Muz. (Praha) 21 (2013) 240-248 (in Czech).
[30] R.L. Frost, J. Čejka, J. Sejkora, D. Ozdín, S. Bahfenne, E.C. Keeffe, J. Raman Spectrosc. 40 (2009) 1907-1910.

[31] J. Čejka, R.L. Frost, J. Sejkora, E.C. Keefee, J. Raman Spectrosc. 40 (2009) 1464 1468.

[32] R.L. Frost, J. Sejkora, J. Čejka, E.C. Keeffe, J. Raman Spectrosc. 40 (2009) 1546 1550.

[33] R.L. Frost, S.J. Palmer, Y. Xi, J. Čejka, J. Sejkora, J. Plášil, Spectrochim. Acta A Mol Biomol. Spectrosc. 103 (2013) 431-434.

[34] J. Sejkora, J. Čejka, R. Malíková, A. López, Y. Xi, R.L. Frost, Spectrochim. Acta A130 (2014) 83-89.

[35] J. Čejka, J. Sejkora, I. Macek, R.L. Frost, A. López, R. Scholz, Y. Xi, Spectrochim. Acta A126 (2014) 157-163.

[36] E.E. Foord, J.E. Taggart Jr., Miner. Mag. 62 (1998) 93-111.

[37] J. Sejkora, R. Škoda, P. Ondruš, J. Czech Geol. Soc. 51 (2006) 159-187.

38] J. Sejkora, J. Cícha, I. Jebavá, Bull. Miner. Petrol. Odd. Nár. Muz. (Praha) 19 (2011) 1-26 (in Czech).

[39] J.W. Anthony, R.A. Bideaux, K.W. Bladh, M.C. Nichols, Handbook of Mineralogy Vol. 4, Arsenates, phosphates, vanadates, Mineral data publishing, Tucson, Arizona, 2000. 680 pp.

[40] A.R. Graham, Univ. Toronto Stud. Geo. Ser. 52 (1948) 39-53.

[41] H. Cid-Dresdner, Zeit. Kristal. 121 (1965) 87-113.

42] U. Kolitsch, G. Giester, Mineral. Mag. 64 (2000) 905-913.

[43] P. Ondruš, ZDS - software for analysis of X-ray powder diffraction patterns Version 6.01. User's guide, Prague, 1995.

[44] C.W. Burnham, Carnegie Inst. Wash. Yearb. 61 (1962) 132-135.

[45] K. Nakamoto, Infrared and Raman Spectra of Inorganic Coordination Compounds, J. Wiley and Sons, New York, 1986.

[46] P. Keller, N. Jb. Miner. Mh. (H.11) (1971) 491-510.

[47] P. Keller, N. Jb. Miner. Abh. 117 (1972) 217-252.

[48] P. Keller, N. Jb. Miner. Abh. 119 (1973) 310-334.

[49] P. Keller, N. Jb. Miner. Abh. 120 (1974) 229-269.

[50] V.V. Pechkovskii, R. Ya. Mel'nikova, E.D. Dzyuba, T.I. Baranikova, M.V Nikanovich, Atlas of Infrared Spectra of Phosphates. Orthophosphates, Nauka Moscow, 1981 (in Russian).

[51] J.A. Goldsmith, S.D. Ross, Spectrochim. Acta A24 (1968) (1968) 2131-2137.

52] R.H.P. Devamani, M. Alagar, Nano Biomed. Eng. 5 (2013) 116-120.

[53] J.M. Aguirre, A. Gutiérrez, O. Giraldo, J. Braz. Chem. Soc. 22 (2011) 546-551.

[54] R.L. Frost, W.N. Martens, L. Rintoul, E. Mahmutagic, J.T. Kloprogge, J. Raman Spectrosc. 33 (2002) 252-259.

[55] E. Libowitzky, Monatsh. Chem. 130 (1999) 1047-1059. 